\title{
Regions of pollution with particulate matter in Poland
}

\author{
Kacper Rawicki, Matgorzata Czarnecka, and Jadwiga Nidzgorska-Lencewicz
}

Department of Meteorology and Landscape Architecture, West Pomeranian University of Technology in Szczecin, ul. Papieża Pawła VI 3, 71-459 Szczecin, Poland

\begin{abstract}
The study presents the temporal and spatial variability of particulate matter concentration in Poland in the calendar winter season (December-February). The basis for the study were the hourly and daily values of particulate matter $\mathrm{PM}_{10}$ concentration from the period 2005/06 2014/15, obtained from 33 air pollution monitoring stations. In Poland, the obligation to monitor the concentration of the finer fraction of particles smaller than $2.5 \mu \mathrm{m}$ in aerodynamic diameter was introduced only in 2010 . Consequently, data on $\mathrm{PM}_{2.5}$ concentration refer to a shorter period, i.e. $2009 / 10$ - 2014/15, and were obtained from 23 stations. Using the cluster analysis (k-means method), three regions of comparable variability of particulate matter concentration were delineated. The largest region, i.e. Region I, comprises the northern and eastern central area of Poland, and its southern boundary is along the line Gorzów Wlkp-Bydgoszcz-KoninLódź-Kielce-Lublin. Markedly smaller Region II is located to the south of Region I. By far the smallest area was designated to Region III which covers the south west area of Poland. The delineated regions show a marked variability in terms of mean concentration of both PM fractions in winter $\left(\mathrm{PM}_{10}\right.$ : region I - $33 \mu \mathrm{g} \cdot \mathrm{m}^{-3}$, region II - $55 \mu \mathrm{g} \cdot \mathrm{m}^{-3}$, region III - 83 $\mu \mathrm{g} \cdot \mathrm{m}^{-3} ; \mathrm{PM}_{2,5}$ : region I - $35 \mu \mathrm{g} \cdot \mathrm{m}^{-3}$, region II $-50 \mu \mathrm{g} \cdot \mathrm{m}^{-3}$, region III - 60 $\left.\mu \mathrm{g} \cdot \mathrm{m}^{-3}\right)$ and, in the case of $\mathrm{PM}_{10}$, the frequency of excessive daily limit value.
\end{abstract}

\section{Introduction}

Almost all winter seasons in Poland, as in other countries in Central and East-Central Europe, are characterised by very high concentrations of particulate matter $\mathrm{PM}_{10}$ and $\mathrm{PM}_{2.5}$. The main source of this phenomenon is increased emission of particulate pollutants generated by combustion processes in stationary sources, predominantly the municipal and household sector. Data provided by IOŚ-PIB [1] show that combustion of fuels for energy generation, mainly coal in stationary sources [2], accounts for approximately $75 \%$ of $\mathrm{PM}_{10}$ national emission and almost $100 \%$ of $\mathrm{SO}_{2}$ national emission. Aerosanitary situation is determined by pollution emission values as well as by weather conditions which, on the one hand, result in intensification of heating process and, on the other, may contribute to effective dispersion or accumulation of pollutants leading to smog situations [3-9].

Particulate matter (PM), also known as particulates, is a complex mixture of different chemical components including water soluble ions, trace metals and organic compounds 
which originate from a wide range of natural and anthropogenic sources [10-12]. The negative effect of particulates on human health is widely documented in literature on the subject [13-16]. The current available data indicate that atmospheric PM pollution is the $6^{\text {th }}$ (out of 43 taken into consideration) leading risk factor contributing to more than 3 million deaths worldwide every year [17]. The International Agency for Research on Cancer has classified air pollution in general, as well as PM as a separate component of air pollution mixtures, as carcinogenic [18]. The report by European Environmental Agency [19] states that in 2015, a total of $19 \%$ of the EU-28 urban population was exposed to $\mathrm{PM}_{10}$ levels above the daily limit value $\left(50 \mu \mathrm{g} \cdot \mathrm{m}^{-3}\right)$. Additionally, the report indicates that $7 \%$ of the EU-28 urban population was exposed to $\mathrm{PM}_{2.5}$ levels above the EU limit value. Taking into account the stricter guidelines of WHO, these percentages increase accordingly for $\mathrm{PM}_{10}$ up to $53 \%$, for $\mathrm{PM}_{2.5}$ - up to $82 \%$. The latest report by WHO [20] on air quality in cities is even more alarming. The assessment is based on mean annual $\mathrm{PM}_{2.5}$ concentration in cities and, according to the report, 33 out of 50 most polluted cities in Europe are located in Poland. Among the EU-28 member states, Poland is ranked as being the $3^{\text {rd }}$ country with the highest estimated number of premature deaths (46 020 a year!) attributed to $\mathrm{PM}_{2.5}$ [19].

The aim of the present paper is to determine the regions of Poland which are characterised by similar variability of PM concentration in the winter season.

\section{Materials and methods}

The study was based on hourly and daily values of particulate matter $\mathrm{PM}_{10}$ concentration in the calendar winter season (December-February) in the period 2005/06 2014/15, obtained from 33 air pollution monitoring stations. In Poland, the obligation to monitor the concentration of the finer fraction of particles smaller than $2.5 \mu \mathrm{m}$ in aerodynamic diameter was introduced only in 2010. Consequently, data on $\mathrm{PM}_{2.5}$ concentration refer to a shorter period, i.e. 2009/10 - 2014/15, and were obtained from only 23 stations with complete measurement series. The values of hourly and daily concentration were characterised per various time steps (month, season, multiannual period) with the use of mean and maximum values, standard deviation, upper and lower quartile, coefficient of variation, and the number of days on which the applicable EU limit value for $\mathrm{PM}_{10}$ was exceeded. The aforementioned characteristics of $\mathrm{PM}_{10}$ which were obtained from a longer measurement series and additionally refer to the finer fraction of particulate matter $(2.5 \mu \mathrm{m})$ were analysed using the cluster analysis method. The present study employs $k$-means (Euclidean distance) which belongs to non-hierarchical cluster analysis methods. This method allows determination of $k$ of the clusters characterised by the possibly greatest difference. The analysis was made using Statistica 12 software which includes implementation of a v-fold cross-validation test allowing identification of the optimum number of clusters. Various combinations (sets) were analysed, taking into consideration all as well as some of the aforementioned $\mathrm{PM}_{10}$ characteristics, according to hourly and daily values. In the end, three regions and their areas were determined on the basis of compilation of four characteristics: lower and upper quartile, variation coefficient of hourly concentration values, and the number of days on which the daily limit value was exceeded. The fact that identical results were obtained in the analysis which additionally included other characteristics of $\mathrm{PM}_{10}$ concentration, i.e. means and standard deviation (also for daily means), only confirms the obtained delineation of the regions.

\section{Results and discussion}


The area of the three regions of pollution with particulate matter in the calendar winter season in presented in Fig. 1 Region I was found to be the largest in area, covering the Pomeranian and Masurian Lakeland, and the Masovian Lowland. Region II was generally classified as covering the Greater Poland Lowland, Silesian Lowland, and the Silesian Upland, Lesser Poland and Lublin Upland. Region III was found to be by far the smallest in area, and comprised 5 cities located in the south of Poland in poorly ventilated basins and well developed river valleys.

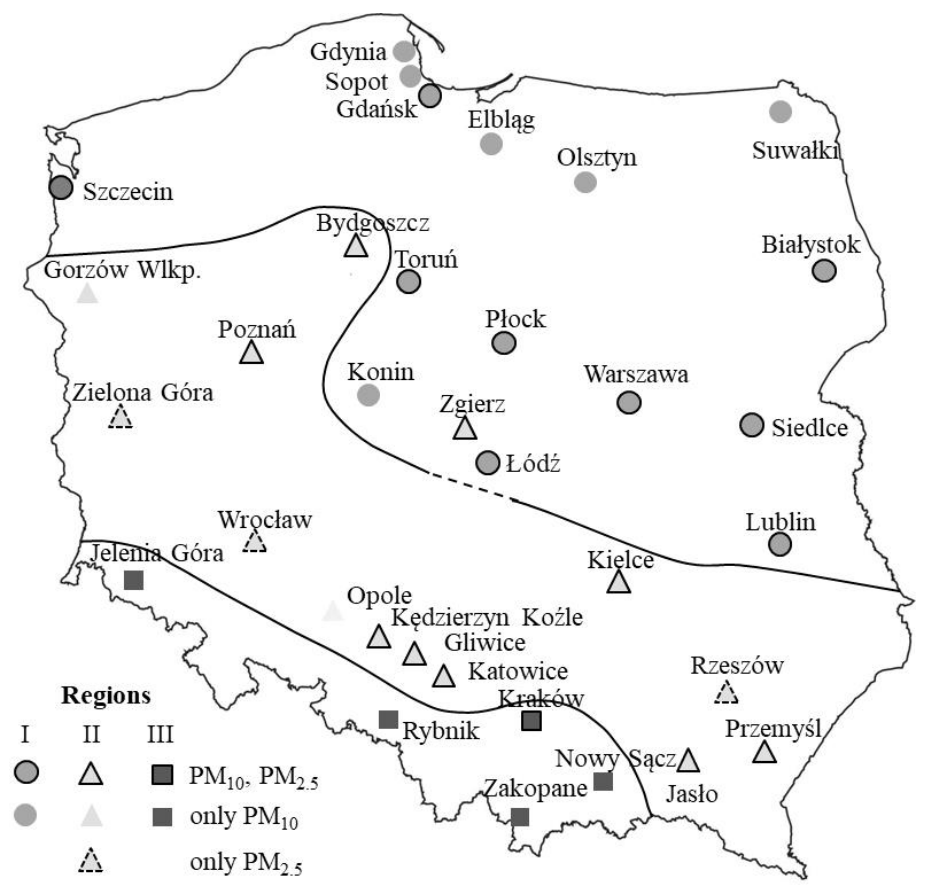

Fig. 1. Regions of pollution with particulate matter during calendar winter (Dec-Feb).

Variation in terms of pollution with PM between the delineated regions is most clearly demonstrated by $\mathrm{PM}_{10}$ concentrations in winter. In region $\mathrm{I}$, the concentration is approximately $33 \mu \mathrm{g} \cdot \mathrm{m}^{-3}$. By comparison, in region II the concentration is approximately 1.5

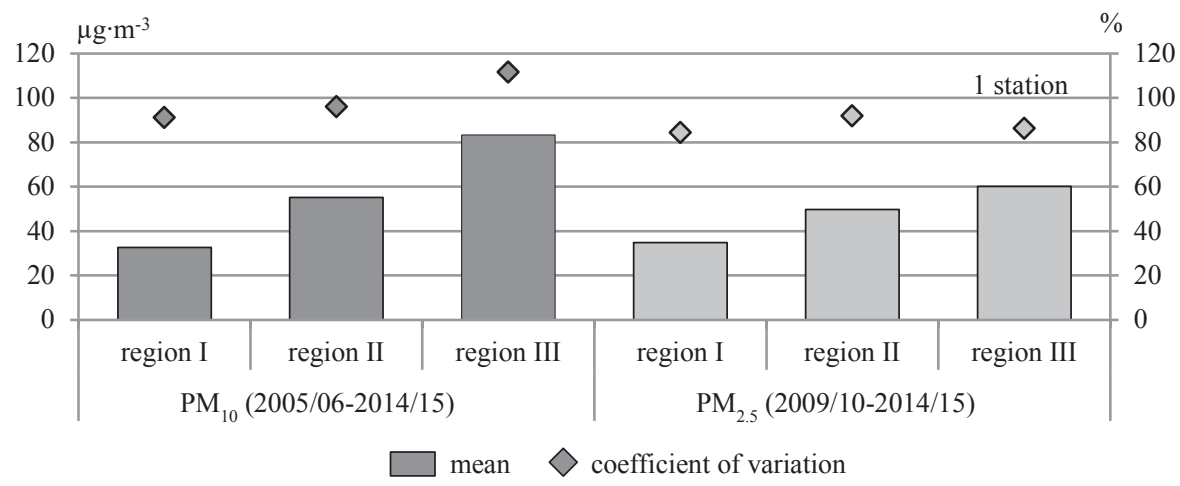

Fig. 2. Mean $\left(\mu \mathrm{g} \cdot \mathrm{m}^{-3}\right)$ and coefficient of variation (\%) of hourly concentrations of particulate matter in designated regions. 
times higher and in region III it is as much as 2.5 times higher. The differences between mean $\mathrm{PM}_{2.5}$ concentrations are significantly smaller. This can result from the fact that the data series was shorter and did not include the four winter seasons from 2005/06 to 2008/09, which were characterised by high variability in $\mathrm{PM}_{10}$ concentration (Tab. 1, Fig. 2).

The most polluted region III is distinguished by not only higher average particulate matter concentration but also by much higher variability of $\mathrm{PM}_{10}$ concentration. In this region, variation coefficient of hourly $\mathrm{PM}_{10}$ concentrations between the winter seasons amounts to approximately $112 \%$, whereas in regions I and II it does not exceed $100 \%$. In the latter regions, greater difference in terms of variability of particulate matter concentration are found for $\mathrm{PM}_{2.5}$ fraction rather than $\mathrm{PM}_{10}$.

Table 1. Mean and maximum hourly concentrations of $\mathrm{PM}_{10}\left(\mu \mathrm{g} \cdot \mathrm{m}^{-3}\right)$ in designated regions during winter (Dec-Feb) from 2005/06 to 2014/15.

\begin{tabular}{|c|c|c|c|c|c|c|}
\hline \multirow{2}{*}{$\begin{array}{c}\text { Winter } \\
\text { (XII-II) }\end{array}$} & \multicolumn{2}{|c|}{ Region I } & \multicolumn{2}{c|}{ Region II } & \multicolumn{2}{c|}{ Region III } \\
\cline { 2 - 7 } & mean & max & mean & max & mean & max \\
\hline $2005 / 06$ & 41.2 & 599.8 & 74.0 & 769.0 & 105.9 & 1052.0 \\
\hline $2006 / 07$ & 21.6 & 252.3 & 32.5 & 354.0 & 51.6 & 455.0 \\
\hline $2007 / 08$ & 25.8 & 460.9 & 43.8 & 400.4 & 79.4 & 671.0 \\
\hline $2008 / 09$ & 34.0 & 375.8 & 62.2 & 865.4 & 77.3 & 618.0 \\
\hline $2009 / 10$ & 40.4 & 487.5 & 69.0 & 732.0 & 101.5 & 771.0 \\
\hline $2010 / 11$ & 33.6 & 344.3 & 66.5 & 687.0 & 105.4 & 763.0 \\
\hline $2011 / 12$ & 32.0 & 705.0 & 52.6 & 639.0 & 78.0 & 842.0 \\
\hline $2012 / 13$ & 34.9 & 483.6 & 56.2 & 552.0 & 86.2 & 1258.0 \\
\hline $2013 / 14$ & 31.5 & 328.7 & 48.7 & 456.7 & 74.4 & 847.0 \\
\hline $2014 / 15$ & 30.5 & 433.6 & 46.4 & 425.3 & 70.9 & 985.0 \\
\hline
\end{tabular}

In all regions, on average, the highest $\mathrm{PM}_{10}$ concentration was recorded in the winter season of 2005/06, and the lowest (by almost two times) in the subsequent winter season of 2006/07 which, according to thermal conditions classification by Lorenc [21], was classified as very warm (Tab. 1). In this particular season, across the country, also the absolute maximum hourly concentration values were by far the lowest in the 10-year long period under analysis. The maximum hourly concentrations were recorded in all of the regions in different winter seasons, yet in each case the values exceeded the mean seasonal values by more than 10 times. In the analysed period, the differences between the mean seasonal $\mathrm{PM}_{10}$ concentration did not exceed $20 \mu \mathrm{g} / \mathrm{m}^{3}$ in region I, in region II the difference was twice as high, and in region II - approximately $54 \mu \mathrm{g} / \mathrm{m}^{3}$.

The regions also demonstrate substantial variation in terms of the frequency of the daily $\mathrm{PM}_{10}$ limit value being exceeded (Fig. 3). In the most polluted region III, excessive daily concentration is recorded on more than half of the days of the calendar winter, in region II approximately $38 \%$, and in region I - only on $16 \%$ of days. The first of the analysed periods, i.e. 2005/06, was characterised by on average the highest $\mathrm{PM}_{10}$ concentration values and frequent exceeding of the daily limit value. However, in other winter seasons 


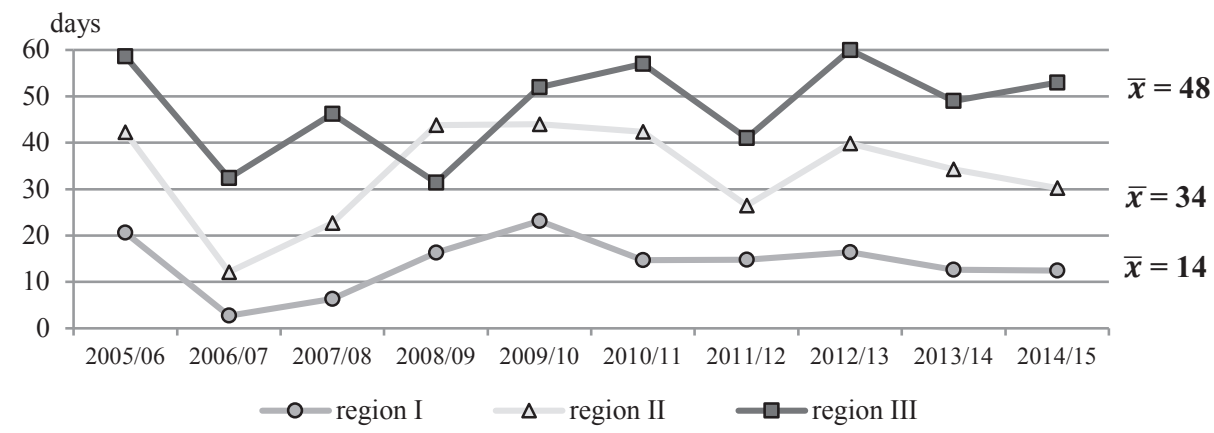

Fig. 3. Number of days exceeding the daily limit value of $\mathrm{PM}_{10}$ in designated regions during the winter (Dec-Feb) from 2005/06 to 2014/15.

under analysis, the UE limit value was exceeded with comparable and at times even higher frequency, depending on the region. In region III the daily limit value was exceeded with similar frequency (on approximately $2 / 3$ of the days) also in 2012/13. In region II EU limit value was exceeded on more than 40 days in subsequent winter seasons, i.e. 2008/09, 2009/10 and 2010/11, and in region I in the winter of 2009/10.
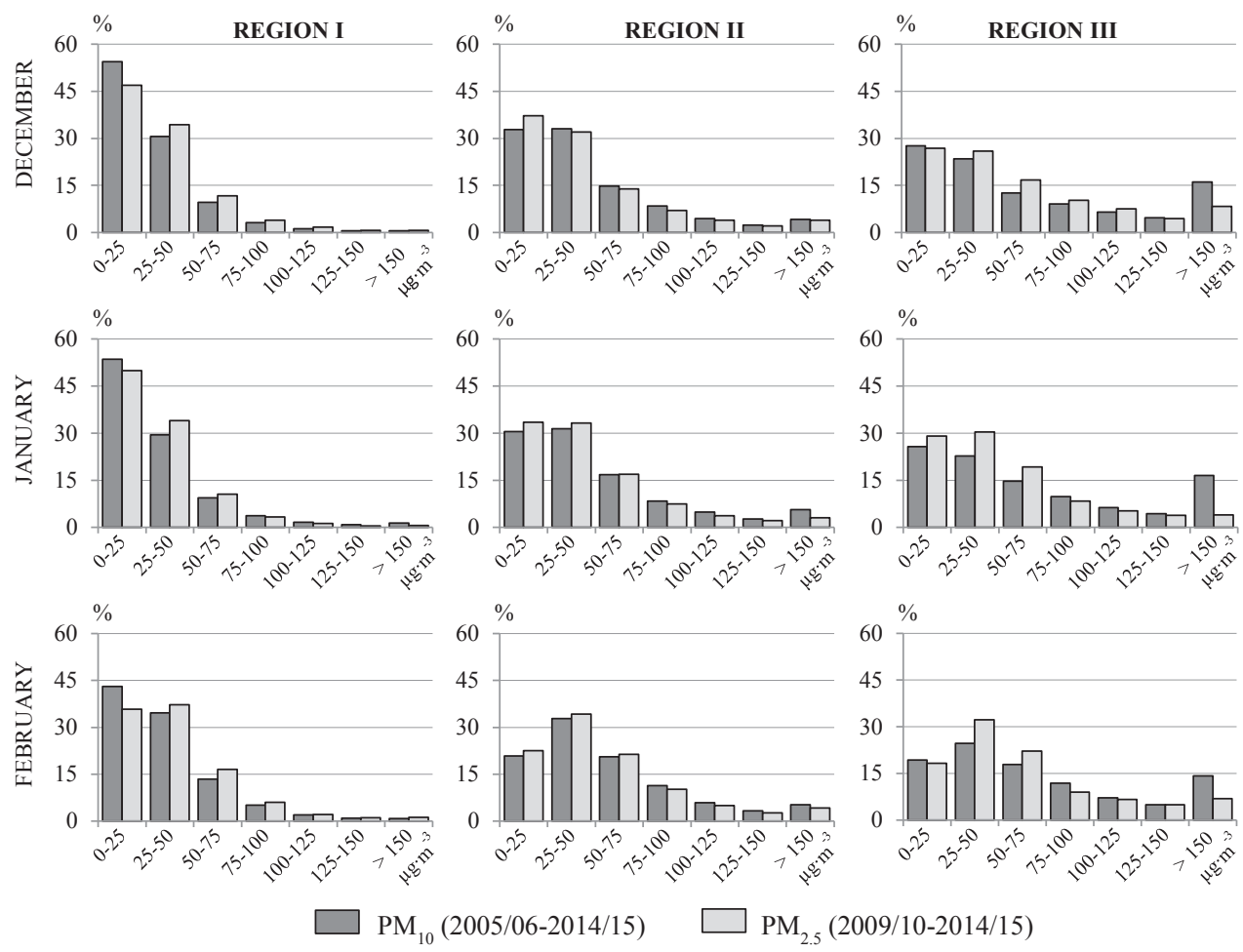

Fig. 4. Frequency distribution of hourly concentrations of particulate matter in designated regions by month.

The characteristics of both fractions of particulate matter is supplemented by frequency histograms of the adopted hourly concentration values according to the three months of the calendar winter season (Fig. 4). In all regions, distribution of the adopted concentration range in December and January shows some similarity, yet in February the distribution is 
slightly different. In region I, the prevalent concentration values do not exceed $25 \mu \mathrm{g} / \mathrm{m}^{3}-$ recorded on more than half of the days in December and January. In regions II and III, in both aforementioned months, the concentration values of $25-50 \mu \mathrm{g} / \mathrm{m}^{3}$ were recorded only slightly less frequently. However, in February, such concentration values are predominant particularly in region II. In region I, hourly particulate matter concentration of more than $100 \mu \mathrm{g} / \mathrm{m}^{3}$ accounted for less than $4 \%$ of the cases in all winter months.

\section{Summary}

The extent of the regions marked by specific values of pollution with particulate matter in the calendar winter season is generally consistent with the increasing from the north to the south emission values and worsening conditions of pollutants dispersion and deposition. The increase in emission results from high concentration of industrial, as well as household and traffic sources due to high population density [22, 23]. The degree of dispersion is dependent on atmospheric conditions and topographic factors [2, 3, 5-9, 24, 25]. Poor conditions for natural ventilation in the south of Poland are associated with low wind speed, greater frequency and duration of atmospheric calm, less frequently occurring unstable equilibrium, and more frequent surface inversions [4, 24, 25], including orographic inversions.

The three regions delineated on the basis on the results of the 10-year long measurement series of $\mathrm{PM}_{10}$ particulate matter concentration are predominantly characterised by differences in mean seasonal concentration values and frequency of exceeding the daily limit value. The results are representative as the analysed winter seasons include not only the winter seasons marked by average thermal conditions, but the winter seasons classified as very warm as well as cold. Undoubtedly, extending the measurement series and including a greater number of stations monitoring $\mathrm{PM}_{2.5}$ fraction would allow to revise the delineation of the regions determined on the basis of the results for the calendar winter seasons in the period 2005-2015.

\section{References}

1. Instytut Ochrony Środowiska - Państwowy Instytut Badawczy (IOŚ-PIB), Warszawa, Krajowy bilans emisji $\mathrm{SO}_{2}, \mathrm{NO}_{X}, \mathrm{CO}, \mathrm{NH}_{3}, \mathrm{NMLZO}$, pytów, metali ciężkich i TZO w uktadzie klasyfikacji SNAP i NFR. Raport podstawowy (2015)

2. M. Reizer, K. Juda-Rezler, Air Qual Atmos Health, 9, 5, (2016)

3. M. Czarnecka, J. Nidzgorska - Lencewicz, Annual Set The Environment Protection, 17, (2015)

4. J. Nidzgorska - Lencewicz, M. Czarnecka, Theor Appl Climat, 119, 3-4, (2015)

5. M. Czarnecka, J. Nidzgorska - Lencewicz, Env. Prot. Eng. 44, 2, (2017)

6. T. Olszowski, Ecol Chem Eng S. 22, 3, (2015)

7. J. Jędruszkiewicz, B. Czernecki, M. Marosz, Inter. J Environ. Health Res., (2017)

8. B.Czernecki,M. Połrolniczak, L. Kolendowicz, M. Marosz, S. Kendzierski, N. Pilguj, J Atmos Chem, 74, (2017)

9. R. Oleniacz, M. Bogacki, M. Rzeszutek, A. Kot, Ochrona powietrza w teorii i praktyce (red. J. Konieczyński) 2, (2014)

10. W. Rogula-Kozłowska, G. Majewski, P.O. Czechowski, Environ Monit Assess, 187, (2015)

11. G. Majewski, W. Rogula-Kozłowska, Theor Appl Climatol 125, (2016) 
12. A. Zwozdziak, M.I. Gini, L. Samek, W. Rogula-Kozlowska, I. Sowka, K. Eleftheriadis, J Aerosol Sci, 103, 38-52 (2017)

13. K. Widziewicz, W. Rogula-Kozłowska, K. Loska, Atmos Pollut Res, 7, 884-894 (2016)

14. M. Tainio, J. Kukkonen, Z. Nahorski, Arch Environ Prot, 36,1, 29-39 (2010)

15. L. Shi, A. Zanobetti, I. Kloog, B. A. Coull, P. Koutrakis, S. J. Melly, J.D. Schwart, Environ Health Perspect, 124,1, 46-52 (2015)

16. F. Dominici, R.D. Peng, M.L. Bell, L. Pham, A. McDermott, S.L. Zeger et al., JAMA, 295, 10, 1127-1134 (2006)

17. S.S. Lim, T. Vos, A.D. Flaxman, G. Danaei et al., Lancet, 380, 2224-2260, (2012)

18. International Agency for Research on Cancer (IARC), Outdoor air pollution a leading environmental cause of cancer deaths, Press Release 221 (2013), (http:// www.iarc.fr/en/media-centre/iarcnews/pdf/pr221_E. pdf) accessed 31 October 2017.

19. European Environment Agency (EEA), Air quality in Europe - 2017 report, 13 (2017)

20. World Health Organization (WHO), WHO global urban ambient air pollution database (update 2016). Ambient (outdoor) air pollution database, by country and city

(http://www.who.int/phe/health_topics/outdoorair/databases/cities/en/) accessed 31 October 2017

21. H. Lorenc, Termiczno-opadowa ocena klimatycznych sezonów roku w Polsce oraz tendencje czasowo-przestrzenne. Projekt badawczy M-9, IMGW, Maszynopis, (2000)

22. Central Statistical Office (GUS), Environment. Statistical Information and Elaborations, Warsaw (2015)

23. Państwowy Monitoring Środowiska - Inspekcja Ochrony Środowiska, Ocena jakości powietrza $w$ strefach $w$ Polsce za rok 2016. Warszawa (2017)

24. A. Palarz, Prace Geograficzne, 138, 29-43 (2014)

25. A. Bokwa, Prace Geograficzne, 126, 41-51 (2011) 